AperTO - Archivio Istituzionale Open Access dell'Università di Torino

\title{
Management control in Italian SMEs
}

\section{This is the author's manuscript}

Original Citation:

Availability:

This version is available http://hdl.handle.net/2318/1607586

since 2018-09-17T23:28:49Z

Published version:

DOI:10.1504/GBER.2017.10004434

Terms of use:

Open Access

Anyone can freely access the full text of works made available as "Open Access". Works made available under a Creative Commons license can be used according to the terms and conditions of said license. Use of all other works requires consent of the right holder (author or publisher) if not exempted from copyright protection by the applicable law. 


\section{INDERSCIENCE Ontine The online platform for Inderscience Publishers journal content}

\begin{tabular}{|c|c|c|c|c|}
\hline Home & Inderscience Publishers & Subscribe & Authors & rarians \\
\hline & words / phrases / DOI / ISSN / authors / keywords / etc. & This Journal & Search & Advanced search \\
\hline
\end{tabular}

Home > Global Business and Economics Review > List of Issues > Volume 19, Issue 5 > Management control in Italian SMEs

$<$ Previous article

Next article >

\section{Management control in Italian SMEs}

Laura Broccardo , Elisa Giacosa , Francesca Culasso ， Alberto Ferraris

https://doi.org/10.1504/GBER.2017.086781

Abstract PDF

\section{Abstract}

The main goal of this research is to investigate management and implications issues with regard to performance measurement systems (PMSs) in small and medium firms (SMEs) in Italy. In particular, the aim is to comprehensively understand the use of management accounting tools in Italian SMEs. Indeed, appropriate managerial tools are relevant in firm management, especially for the improvement and growth of firms in this turbulent international scenario. The focus is on SMEs - in some countries such as Italy, small and medium firms play an important role; however, mainstream studies in management literature focus more on large firms. The method used to conduct this study is a survey that collected a high level of data on PMSs. The sample includes 309 Italian SMEs. The main findings concern the use and adoption of management control tools. In addition, the analysis of management issues is based on both major national and international literature and empirical evidence and adopts the newly emerging beyond budgeting theory. Finally, this study contributes to a better understanding of the behaviour of SMEs with regard to the management and control of their performance. In particular, this research highlights that budgets are still an important managerial tool for SMEs.

Keywords: management control, Italy, budget, SMEs, managerial issues, better budgeting

4 SHARE

Purchase this article Subscribe this journal

Click 'Add to cart' to add this article to the shopping cart. This article price is $\$ 40.00$. You may review the list of added articles prior to making the actual purchase on the shopping cart page.

\section{Global Business and Economics Review}

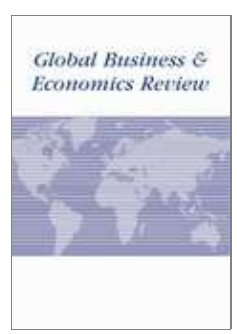

Print ISSN: $1097-4954$ Online ISSN: $1745-1329$

$$
\begin{array}{ll}
\text { - Current issue } & \text { - Subscribe } \\
\text { - List of issues } & \text { - Get TOC alerts } \\
& \text { - About this journal }
\end{array}
$$

\section{Article / Chapter Tools}

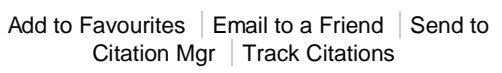

\section{Related Content Search}

By Keyword

$$
\begin{aligned}
& \square \text { management control } \\
& \square \text { Italy } \\
& \square \text { budget } \\
& \square \text { SMEs } \\
& \square \text { managerial issues } \\
& \square \text { better budgeting }
\end{aligned}
$$

By Author
$\square$ Laura Broccardo
$\square$ Elisa Giacosa
$\square$ Francesca Culasso
$\square$ Alberto Ferraris

\section{Search}

Most Read

Most Cited 


\title{
Management control in Italian SMEs
}

\section{Laura Broccardo*, Elisa Giacosa, Francesca Culasso and Alberto Ferraris}

\author{
Department of Management, \\ University of Turin, \\ Corso Unione Sovietica 218 bis, \\ 10134 Turin (TO), Italy \\ Fax: 39-011-6706012 \\ Email: laura.broccardo@unito.it \\ Email: elisa.giacosa@unito.it \\ Email: francesca.culasso@unito.it \\ Email: alberto.ferraris@unito.it \\ *Corresponding author
}

\begin{abstract}
The main goal of this research is to investigate management and implications issues with regard to performance measurement systems (PMSs) in small and medium firms (SMEs) in Italy. In particular, the aim is to comprehensively understand the use of management accounting tools in Italian SMEs. Indeed, appropriate managerial tools are relevant in firm management, especially for the improvement and growth of firms in this turbulent international scenario. The focus is on SMEs - in some countries such as Italy, small and medium firms play an important role; however, mainstream studies in management literature focus more on large firms. The method used to conduct this study is a survey that collected a high level of data on PMSs. The sample includes 309 Italian SMEs. The main findings concern the use and adoption of management control tools. In addition, the analysis of management issues is based on both major national and international literature and empirical evidence and adopts the newly emerging beyond budgeting theory. Finally, this study contributes to a better understanding of the behaviour of SMEs with regard to the management and control of their performance. In particular, this research highlights that budgets are still an important managerial tool for SMEs.
\end{abstract}

Keywords: management control; Italy; budget; SMEs; managerial issues; better budgeting.

Reference to this paper should be made as follows: Broccardo, L., Giacosa, E., Culasso, F. and Ferraris, A. (2017) 'Management control in Italian SMEs', Global Business and Economics Review, Vol. 19, No. 5, pp.632-647.

Biographical notes: Laura Broccardo holds a $\mathrm{PhD}$ in Business Administration in 2010. Currently, she is an Assistant Professor in Business Administration at the Department of Management, University of Turin, Italy. She was an Erasmus Visiting Professor in some foreign universities. She teaches management accounting and business organisation courses (Italian and English undergraduate) and the business organisation and process management course (graduate). Her research interests are in management accounting, cost management, strategic management, governance, and the organisational and behavioural aspects of accounting, on which several international publications were focused. She is a fellow of the EuroMed Academy of Business. 
Elisa Giacosa is an Assistant Professor in Business Administration at the University of Turin, Italy. Her research interests are in crisis management, fashion firms, net economy firms, and financial analysis. She teaches the financial accounting (Italian undergraduate) and net economy courses (Italian undergraduate).

Francesca Culasso is an Associate Professor in Business Administration at the University of Turin, Italy. Her research interests are in management accounting, cost management, strategic management, governance, risk management, and the organisational and behavioural aspects of accounting. She teaches the management accounting (Italian and English undergraduate) and business organisation and process management courses (graduate).

Alberto Ferraris received his $\mathrm{PhD}$ in Business and Management from the Department of Management, University of Turin (Italy) in 2015. He is a Post Doc Researcher at the University of Turin - Department of Management. Currently, he is an associate member (AM-EMAB) of the EuroMed Research Business Institute and member of the John H. Dunning Centre for International Business, Henley Business School. He is an author of several academic and scientific articles and member of the EuroMed Research Business Institute Research Group on 'Multinational enterprises and corporate governance'. He is also a Research Fellow of the Laboratory for International and Regional Economics, Graduate School of Economics and Management, Ural Federal University.

This paper is a revised and expanded version of a paper entitled 'How Italian SME manage and control their performance?' presented at 8th Annual Conference of the EuroMed Academy of Business, Verona, Italy, 16-18 September 2015.

\section{Introduction}

In the last several years, an increasing amount of attention has been given to performance measurement systems (PMSs) in small- and medium-sized enterprises. Based on the existing research, certain managerial tools have demonstrated an important influence on firms' management and been shown to improve financial management in these firms.

The management control system (MCS) is the basis for a PMS that supports the decision-making process in the areas of financial and taxation as well, which is why some advanced tools have been developed in the last several years. For SMEs, management complexity is increasing, and the need for advanced tools to overcome managerial difficulties is growing.

In small- and medium-sized, firms (Aram and Cowen, 1990), if the literature also underlines that management accounting tools empower managerial capabilities; these tools are not extremely widespread or correctly adopted by firms.

Consequently, it is important to understand how the management accounting system is evolving in these specific types of firms, considering that appropriate managerial tools have an important influence on firms' management.

What is important to underline is that small- and medium-sized enterprises are characterised by a particular strategic model as they search for niche positioning and the strategic process is unstructured (Visconti, 2008). Another feature of these types of firms, 
which is considered a consequence of firm size (Engelen and van Essen, 2013), is the management model that assumes that the entrepreneur assumes all management responsibilities and, consequently, the management corresponds to the ownership (Corbetta, 1995).

This research is also supported by Chenhall (2003), which, in his survey of contingency-based research on MCSs, indicates that few studies on MCSs include size as a contextual variable. Consequently our study contributes to gaining a better understanding of the behaviour of small- and medium-sized firms, which play an important role in the economy in Italy as well as in Europe and the USA.

In addition, by analysing a MCS and its tools, we investigate the beyond budgeting theory, which focuses on the key role that covers human resources and is based on the assumption that, in the current economic and globalised market, it is more important to manage 'complexity' than efficiency (de Luca, 2010). Hope and Fraser (2003a, 2003b), the main authors of this movement, proposed a new management model based on employee empowerment and alternative methods of performance management that bypass budgeting. This tool is generally considered useful when the economic environment is stable (de Luca, 2010), but, starting in the nineties, budgeting has been increasingly seen by managers as a process that is too long and complex while not being flexible enough.

Based on these assertions, our study contributes to the literature by discussing whether budgets are still considered useful tools in the Italian context by analysing SMEs in particular, and it verifies whether other complementary tools exist to improve budgeting and avoid budget limitations, as the better budgeting theory states.

This research includes a theoretical framework about SMEs, MCS, beyond and better budgeting theories; a description of the research method and the sample; and the findings, conclusions and implications of the study as well as its limitations.

\section{Literature review}

The MCS provides information to managers and create conditions that drive the organisation and assist managers in making decisions according to their plans and objectives (Fisher, 1998).

Simons (1994) have defined the MCS as "the formal, information-based routines and procedures managers use to maintain or alter patterns in organizational activities". In this way, control is a policy or procedure that assists an organisation in ensuring that its goals and objectives are reached. Management accounting control functions by establishing a standard, receiving feedback on actual performance and taking corrective action whenever actual performance deviates significantly from the planned performance.

One main management accounting tool is a budget, which is described as a common accounting tool that organisations use for implementing strategies (Horngren et al., 2005). Budgets are considered an integral part of MCSs that aim to promote coordination and communication among sub-units within a company, provide a framework for judging performance, and finally, motivate managers and other employees (Horngren et al., 2005).

This tool is generally considered useful for planning and control and is designed to measure performance and give the company a competitive advantage when the economic 
environment is stable (de Luca, 2010). However, since the ' 90 s, managers increasingly see budgeting as a process that is too long, too complex and not flexible enough.

Budgets have been criticised for being too time consuming, imposing a vertical command-and-control structure; creating centralised decision making; stifling initiative; and focusing on cost reduction rather than value creation (Wallander, 1999; Hansen et al., 2003; Hope and Fraser, 2003a, 2003b; Østergren and Stensaker, 2011).

New approaches to management control attempt to respond to budget shortcomings as listed above. It has even been suggested that organisations remove budgets and move 'beyond budgeting' (Hope and Fraser, 2003a, 2003b).

The beyond budgeting approach is based on the premise that the annual budget and budgeting process are broken and need to be replaced with other control mechanisms (Hope and Fraser, 2003a, 2003b). In particular, budgeting focuses on replacing many budget processes with better alternatives (Hansen, 2011).

On the contrary, some researchers (Anthony, 2005; Brusa, 2012; de Luca, 2010; Dematté, 2002; Hirst, 1987; Hope, 2007; Libby and Lindsay, 2003; Merchant, 1985) affirm that budgets are still a useful tool, even if these researchers are also critical of budgets. The main problems seen in this tool include:

- The length of time required to prepare a draft (too much time compared uncertain benefits).

- The stiffness and slowness of the response to the economic environment; an emphasis on quantitative performance, such as monetary and non-qualitative performance.

- The manipulation of the data; the idea of validity at all costs (the budget is 'the law').

- The authorisation to spend money.

- And poor orientation to customer needs and market trends. Managers are often not involved in setting goals, but they are still required to reach them, and budgets are usually too focused on the short term and highlight the gap that exists with the associated strategy.

Consequently, they suggest adding other tools to avoid encountering budget limitations.

Despite this discussion, MCS is important, especially for organisational growth, when coordination and control problems cannot be solved through informal interactions (Jamil and Mohamed, 2013; Thrassou et al., 2014). Hilton (2009) explained that management accounting plays a broader role in organisations by providing a framework and tools for planning and management control. He listed five major goals of management accounting, which include the following:

- providing information for decision making and planning

- assisting managers in directing and controlling operational activities

- motivating managers and other employees to work toward organisational goals

- measuring the performance of activities, subunits, managers and other employees within the organisation

- assessing the organisation's competitiveness by working with other managers to ensure long term survival. 
The main goals of MCS are always the same, but different applications are used in different firms, especially considering firm size and SMEs.

SMEs are a specific set of firms with clear differences from large firms, and some studies underline the significance of SMEs in the economy. In many countries, they represent over $95 \%$ of all businesses, employ approximately $65 \%$ of the workforce and contribute approximately $25 \%$ to the GDP (Ballantine et al., 1998).

In the literature, special attention has been given to SMEs because they are believed to facilitate change in social and attitudinal engineering, shape, legitimise self-employment, and promote new venture creation and entrepreneurship (Bracker and Pearson, 1986; Dangayach and Deshmukh, 2001; Ferraris, 2013).

When analysing the literature, the SME research focuses on (Augustine et al., 2012):

- ownership and decision making; ownership and production control (Lyles, 1993)

- management style and firm performance (Bhutta et al., 2008)

- organisational culture and productivity (Ritchie and Brindley, 2005)

- levels of organisational structure and production performance; stakeholder characteristics (Bhutta et al., 2008)

- matching production methods with the environment (Jonsson and Matsson, 2003); and the use of innovation and training (Soderquist et al., 1997; Bresciani, 2010; Omerzel and Antoncic, 2008).

Some studies (Kraus et al., 2006) underline that SME owners/managers follow autocratic and egocentric management style; as a result, the performance level is very low, and the competitive advantage of SMEs depends on IT infrastructure, cultural dimensions and the strategic use of forecasting planning and control methods.

Consequently, the strategic use of forecasting planning and control methods play an important role in SMEs. Some studies have underlined the poor management of SMEs in many countries.

In addition, some studies highlight the relevance of voluntary certification in the management system. In particular, Giacomarra et al. (2016) provide evidence that internal motivations drive entrepreneurs to adopt voluntary standards, and firms that adopt voluntary standards exhibit better economic performance than non-certified firms, showing that although the adoption of voluntary quality certifications does not have a direct effect in terms of a labour productivity increase, it entails business management improvements.

To gain a better understanding of the MCS in SMEs, it is useful to identify their features. An interesting study (Ates et al., 2013) describes the SMEs as follows. SMEs have a flat structure, which allows clear, uninterrupted streams of communication; in addition, barriers that include limited resources and strategy-oriented processes limit performance measurement in SMEs.

Ates et al. (2013) found that SMEs are more focused on internal and short-term planning and pay less attention to long-term planning. They suggest an appropriate, balanced use of strategic and operational practices and relevant measures to make performance management practices more effective. Therefore, managerial activities such as vision, mission and value development; internal and external communication; changing management; and horizon scanning are recommended areas for improvement. 
For SMEs to operate in a more flexible manner and be more reactive to market changes, they frequently operate with fewer resources and managerial expertise (Garengo, 2009). Indeed, by not having the skills to understand or apply the information (Reddaway et al., 2011), SMEs do not make optimal use of accounting information (Marriott and Marriott, 2000; Sian and Roberts, 2006).

Other studies have also identified the factors that, for SMEs are obstacles to the adoption of management control tools (Garengo et al., 2005) that are strictly tied to having fewer resources. Some researchers identified the lack of human resources, which is always involved in the operational activities (Hudson and Smith, 2000). Other SMEs lack managerial capacity (Marchini, 1995), have limited capital resources, implement poor strategic planning (Marchini, 1995), lack a managerial system and formalised management of processes (Jennings and Beaver, 1997), and believe that management accounting systems cause bureaucratisation (Hvolby and Thorstenson, 2000).

Indeed, when analysing the management control tools that are more frequently adopted by SMEs, it is apparent that these are connected to analyses involving ratios and items that comprise the financial statement. In particular, attention is focused on taxation issues and, as a result, the issues are more relevant for banks (Broccardo, 2009; Bresciani and Oliveira, 2007; Hewa Wellalage and Locke, 2012).

In addition, if the studies on SMEs have been increasing, little attention is given to these firms; the main studies about management accounting systems in SMEs are conducted in Australia, Finland and Denmark (Garengo et al., 2005).

\section{Research questions and method}

\subsection{Method}

The research was conducted via a survey questionnaire (Corbetta et al., 1997), which allows for the collection of a significant amount of data that allow a statistical analysis and an identification of generalisations (Zimmerman, 2001).

Before sending out the questionnaire, we contacted investor relation directors to identify the employees who had the most experience with administration and management control. Subsequently, the questionnaire, together with a letter of introduction and a compilation guide, was sent by mail to the CEO, CFO, and controller or in small companies, directly to the entrepreneur.

The data, both quantitative and qualitative, were collected with an online questionnaire, which was managed by Monkey Survey and analysed using statistical tools. The questionnaire was created in June 2014, and data collection ended in November 2014.

The final document was structured in three main sections:

- general data of the company (Section 1)

- $\quad$ organisational structure (Section 2)

- $\quad$ organisational aspects of management control and associated tools (Section 3). 
The questions focused on different PMSs, organisational features and implementation methods. In addition, the questionnaire included also some 'test questions' to verify the coherence of answers. In accordance with the main literature on these topics (Chenhall, 2003), the evidence was analysed using descriptive statistics.

\subsection{Sample}

The sample focuses on Italian small and medium enterprises with registered offices in the northwestern region of Italy that included different industries to avoid the sector influence. The original sample was composed of 3,901 companies, and we created a random and casual section of the sample comprising 1,800 companies to which we sent the questionnaire. Due to the response rate of $18 \%$, in line with the main literature, the final sample comprises 309 Italian companies.

More details about the sample selection are given below.

Our sample was composed of 3,900 companies, thanks to the collaboration efforts of the Chamber of Commerce of Turin in June 2014. We considered only active companies (that were not closed or in the middle of settlement procedure) with legal head offices in the Piedmont, a region in the northwest of Italy and that had revenues of between $€ 5$ million and $€ 250$ million (referring to CE 364/2004, adopted in Italy on the 1 January 2005 , which separates companies into four different groups based on their size. The sample companies belonged to different economic sectors (manufacturing, services, trading, craftsmanship, agriculture and livestock).

We excluded micro-companies and the smallest companies ( $<€ 5$ million of revenue) to focus on small to medium-sized firms. We then randomly chose 1,800 companies with the program to which the questionnaires were sent.

Finally, 309 companies (18\%) returned the completed questionnaire. Our final sample was composed of 309 companies. The compilation time was approximately three months.

Table 1 Characteristics of the sample

\begin{tabular}{lc}
\hline Industries & $(\%)$ \\
\hline Manufacturing & 60.28 \\
Services & 22.76 \\
Trade & 8.48 \\
Transport & 4.02 \\
Building and construction & 4.02 \\
Agriculture & 0.44 \\
Total & 100 \\
\hline Dimensional features & $(\%)$ \\
\hline Revenues between $€ 5-10 \mathrm{mln}$ & 43.10 \\
Revenues between $€ 10-20 \mathrm{mln}$ & 29.60 \\
Revenues between $€ 20-50 \mathrm{mln}$ & 27.30 \\
Total & 100 \\
\hline
\end{tabular}


In our sample, more than $50 \%$ of the companies had legal head offices in the Turin area (the main city in the Piedmont region, representing the centre of business and economic activities in the region), while $20 \%$ were located in the Cuneo district. These two districts are geographically speaking and the largest areas in the Piedmont.

The main characteristics of the sample are summarised in Table 1.

\subsection{Research questions}

The main research questions are drawn from an extensive analysis of the literature:

RQ1 What are the main features of MCSs in Italian SMEs?

RQ2 Are budgets a widely used tool in the MCS in Italian SMEs?

\section{Findings and discussion}

Regarding the first research question, RQ1: what are the main features of the MCS in Italian SMEs?, we analysed the following data collected by the questionnaire.

It was found that $84.50 \%$ of the sample used some managerial accounting tools, and only $15.20 \%$ affirm that no tools are used in the company.

Exhibit 1 Managerial accounting tool adoption

\begin{tabular}{lcc}
\hline & Does the company use managerial accounting tools? \\
\hline Answer options & Response percent & Response count \\
\hline Yes & $84.8 \%$ & 190 \\
No & $15.2 \%$ & 34 \\
Answered question & & 224 \\
Skipped question & & 85 \\
\hline
\end{tabular}

Consequently, it was interesting to investigate the reason for the lack of adoption of managerial accounting tools. In particular, it was found that $40 \%$ of the companies consider these tools to be too expensive, probably without evaluating the benefits.

Exhibit 2 No adoption of managerial accounting tools

\begin{tabular}{lcc}
\hline \multicolumn{3}{c}{ If not, why? } \\
\hline Answer options & Response percent & Response count \\
\hline The company does not know about these tools & $17.1 \%$ & 6 \\
Too expensive & $40.0 \%$ & 14 \\
Tools are too difficult to use & $14.3 \%$ & 5 \\
The tools are not useful & $17.1 \%$ & 6 \\
Other answers & $17.1 \%$ & 6 \\
Answered question & & 35 \\
Skipped question & & 274 \\
\hline
\end{tabular}


In general, management control is performed internally (75.9\%) because the information is considered confidential and internal capabilities are utilised to save on costs.

Exhibit 3 Managerial control internal/external

\begin{tabular}{lcc}
\hline \multicolumn{3}{c}{ Methods of handling management control } \\
\hline Answer options & Response percent & Response count \\
\hline Internally & $75.9 \%$ & 154 \\
Externally & $3.0 \%$ & 6 \\
Both & $21.2 \%$ & 43 \\
Answered question & & 203 \\
Skipped question & & 106 \\
\hline
\end{tabular}

Regarding the timing when performing management control, it emerged that the greater part of the sample conducts management control activities monthly (60.2\%) and quarterly (20.9\%), showing a high level of attention and interest in the information that emerges from Management Control. This evidence regarding the frequency of management control, underlines the way in which management control tools are involved in the company management. These companies utilise data and information that are found through management control processes to manage the firm and to make operative decisions throughout the year.

Exhibit 4 Managerial control timing

\begin{tabular}{lcc}
\hline \multicolumn{3}{c}{ Reporting and management control timing } \\
\hline Answer options & Response percent & Response count \\
\hline Monthly & $60.2 \%$ & 121 \\
Bimonthly & $2.0 \%$ & 4 \\
Quarterly & $20.9 \%$ & 42 \\
Every four months & $3.0 \%$ & 6 \\
Semi-annually & $2.5 \%$ & 5 \\
Yearly & $3.5 \%$ & 7 \\
When needed & $8.0 \%$ & 16 \\
Answered question & & 201 \\
Skipped question & & 108 \\
\hline
\end{tabular}

Due to the importance given by the companies to management control data and information, we investigate the scope of management control assigned by companies. We discover that management control is used strategically to capture information for better decision-making capabilities (89.5\%) and to define the future strategic goals $(55 \%)$ and in terms of operations to define the selling price (45.5\%) and to improve the drafting of financial statements $(43 \%)$. 
Exhibit 5 Managerial control scope

\begin{tabular}{lcc}
\hline \multicolumn{3}{c}{ In your company, management control is used } \\
\hline Answer options & Response percent & Response count \\
\hline To improve the drafting of financial statements & $43.0 \%$ & 86 \\
To define the selling price & $45.5 \%$ & 91 \\
To obtain information to make better decisions & $89.5 \%$ & 179 \\
To evaluate managers & $17.5 \%$ & 35 \\
To define future strategic goals & $55.0 \%$ & 110 \\
Other & $1.5 \%$ & 3 \\
Answered question & & 200 \\
Skipped question & & 109 \\
\hline
\end{tabular}

Despite the findings that the management control tools are used in a strategic way, the diffusion of an advanced management accounting system is not widespread (see Table 2), as was expected. Indeed, the 'advanced' tools (balanced scorecard, strategy map and more in general business performance models) that are more capable of considering a long-term perspective are adopted only by $14.3 \%$ of the sample.

Table 2 Diffusion of management accounting systems

\begin{tabular}{lccc}
\hline Management accounting systems & Frequency & Percentage & Cumulative percentage \\
\hline None & 39 & 17.4 & 17.4 \\
Basic & 60 & 26.8 & 44.2 \\
Relevant & 93 & 41.6 & 85.7 \\
Advanced & 32 & 14.3 & 100.0 \\
Total & 224 & 100.0 & \\
\hline
\end{tabular}

Indeed, using the data and information to identify the strategic scope, we also expected that the tools that were adopted would be more advanced. Consequently, the strategic decisions in these companies are based on information obtained by traditional tools (Budget, ratio analysis, etc.), which do not help management create a strategic vision.

To gain a better understanding of the use of management control in the sample, in particular, the tools adopted were not only used for forecasting or simulation but especially as a guide for management. We investigate the use of these tools to manage managers and $66.7 \%$ answered affirmatively.

Exhibit 6 Management control: tool for management

\begin{tabular}{lcc}
\hline \multicolumn{2}{c}{ Is the management control used as a tool to manage managers? } \\
\hline Answer options & Response percent & Response count \\
\hline Yes & $66.7 \%$ & 130 \\
No & $33.3 \%$ & 65 \\
Answered question & & 195 \\
Skipped question & & 114 \\
\hline
\end{tabular}


In particular, the responsibilities focus on the centre results $(65.4 \%)$, the costs composition for each centre (64.7\%) and the actions undertaken in each centre (64.7\%).

Exhibit 7 Managerial control responsibilities

\begin{tabular}{lcc}
\hline \multicolumn{3}{c}{ If yes, how the managers are managed } \\
\hline Answer options & Response percent & Response count \\
\hline Sanctions & $3.0 \%$ & 4 \\
Centre result monitoring & $65.4 \%$ & 87 \\
Cost analysis for each centre & $64.7 \%$ & 86 \\
Corrective actions in each centre & $64.7 \%$ & 86 \\
Number of work hours & $18.0 \%$ & 24 \\
Other & $3.8 \%$ & 5 \\
Answered question & & 133 \\
Skipped question & & 176 \\
\hline
\end{tabular}

In response to the second research question, RQ2: is the budget a widely used tool in the MCSs in Italian SMEs?, we investigate the main tools adopted by these types of firms.

Exhibit 8 Managerial control tools

\begin{tabular}{lcc}
\hline \multicolumn{3}{c}{ Which management control tools are adopted? } \\
\hline Answer options & Response percent & Response count \\
\hline Activity-based costing & $20.7 \%$ & 41 \\
Variance analysis & $44.9 \%$ & 89 \\
Ratio analysis (ROE, ROI, ROS, etc.) & $72.7 \%$ & 144 \\
Balanced scorecard & $15.2 \%$ & 30 \\
Balanced scorecard integrated with a risk indicator & $1.0 \%$ & 2 \\
Benchmarking & $13.6 \%$ & 27 \\
Budget & $78.8 \%$ & 156 \\
Co-design & $3.0 \%$ & 6 \\
Simplified analytical accounting (without cost centres) & $21.2 \%$ & 42 \\
Accounting cost centres & $63.6 \%$ & 126 \\
Customer satisfaction ratio & $25.3 \%$ & 50 \\
Productivity ratio & $40.9 \%$ & 81 \\
Strategy map & $0.0 \%$ & 0 \\
Boston consulting group matrix & $0.5 \%$ & 1 \\
Process costing & $3.0 \%$ & 6 \\
ERP system & $30.3 \%$ & 60 \\
Target costing & $7.6 \%$ & 15 \\
Others & $5.1 \%$ & 10 \\
Answered question & & 198 \\
Skipped question & & 111 \\
\hline
\end{tabular}


When examining the management control tools adopted by the companies, the most widely used tools were found to be budgets $(78.8 \%)$, financial statement analyses by ratios $(72.7 \%)$ and accounting cost centres $(63.6 \%)$, underlining that traditional tools are most commonly adopted by these firms. This examination was also confirmed by the previous analysis regarding the diffusion of the MCS. Tools that are more useful for planning the strategic goals, the so-called 'advanced' tools (Table 2), are less commonly adopted by the analysed companies: balanced scorecard $(15.2 \%)$, benchmarking $(13.6 \%)$ and balanced scorecard integrated with a risk indicator $(1 \%)$.

The companies that adopt management control tools perceive a generation of benefits $(94.9 \%)$.

Exhibit 9 Management control: benefits

\begin{tabular}{lcc}
\hline \multicolumn{2}{c}{ Did the adoption of management control tools generate benefits? } \\
\hline Answer options & Response percent & Response count \\
\hline Yes & $94.9 \%$ & 186 \\
No & $5.1 \%$ & 10 \\
Answered question & & 196 \\
Skipped question & & 113 \\
\hline
\end{tabular}

In particular, the main benefit focused on obtaining more correct information $(83.4 \%)$, reducing costs $(60.4 \%)$, avoiding weaknesses $(62 \%)$, managing the employees $(49.7 \%)$ and creating improvements in products and services (45.5\%).

Exhibit 10 Management control: benefits

\begin{tabular}{lcc}
\hline \multicolumn{3}{c}{ Ifyes, what are the benefits? } \\
\hline Answer options & Response percent & Response count \\
\hline Obtain correct information & $83.4 \%$ & 156 \\
Eliminate weaknesses & $62.0 \%$ & 116 \\
Opportunity to reinforce strengths & $31.0 \%$ & 58 \\
More responsibility for the employees & $49.7 \%$ & 93 \\
Improvement in processes & $45.5 \%$ & 85 \\
Improvement in product and services & $17.6 \%$ & 33 \\
Increase in productivity & $21.4 \%$ & 40 \\
Fewer costs & $60.4 \%$ & 113 \\
Others & $0.0 \%$ & 0 \\
Answered question & & 187 \\
Skipped question & & 122 \\
\hline
\end{tabular}

\section{Conclusions and future developments}

This study reveals a widespread implementation of management accounting tools in Italian SMEs. It also emerged that the non-adoption of these tools is due to the expense 
perceived by the companies, who probably perceive the expense without evaluating future economic advantages that may be gained.

The MCS relevance emerges mainly from the monthly frequency of use that demonstrates the true utilisation of information of daily management.

It is interesting that the information derived by management control is used for strategy purposes and to set future strategic goals, but the tools adopted are traditional rather than advanced tools.

This evidence confirms the main literature (Ates et al., 2013), which suggests adopting more appropriate strategic and operational practices to make performance management more effective and identifies vision, mission and value development as recommended areas for improvement. The barriers of strategy-oriented processes limit performance measurement in SMEs.

In addition, it is confirmed that budgets are a central tool in MCSs and highlights that, in the sample analysed, traditional tools are the most widely used. These findings confirm the part of the literature (Anthony, 2005; Brusa, 2012; de Luca, 2010; Dematté, 2002; Hirst, 1987; Hope, 2007; Libby and Lindsay, 2003; Merchant, 1985) that states that budgets are useful tools even if criticisms of budgets are also made. This suggests that the adoption of other tools would circumvent the limits presented by budgets. Indeed, it clearly emerges in this research that tools that are effective for short-term decision making are used to make strategic decision, consequently limiting the strategic vision and mission of these firms.

This paper has both academic and practical implications. The theoretical implications highlight the structure and the tools of management control that are adopted by these types of firms. In addition, this study confirms the part of the literature that states that the budget is not an obsolete tool, even if it also presents some problems. The practical implications are the confirmation of the relevance of less advanced managerial tools that are used to strengthen managerial capabilities. However, budgets are still useful, even if it is necessary to utilise additional tools to overcome its limitations.

Future development can enlarge the sample and comparisons with other countries. In addition, it may be interesting to investigate the limitations perceived by the companies regarding the actual management control structure.

\section{References}

Anthony, R.N. (2005) Sistemi di controllo: analisi economiche per le decisioni aziendali, McGraw-Hill, Milano.

Aram, J. and Cowen, S. (1990) 'Strategic planning in the small business', Long Range Planning., Vol. 23, No. 6, pp.63-70.

Ates, A., Garengo, P., Cocca, P. and Bititci, U. (2013) 'The development of SME managerial practice for effective performance management', Journal of Small Business and Enterprise Development, Vol. 20, No. 1, pp.28-54.

Augustine, B., Bhasi, M. and Madhu, G. (2012) 'Linking SME performance with the use of forecasting planning and control: empirical findings from Indian firms', European Journal of Scientific Research, Vol. 73, No.1, pp.86-105.

Ballantine, J., Levy, M. and Powell, P. (1998) 'Evaluating information systems in SMEs: issues and evidence', European Journal of Information Systems, Vol. 7, No. 4, pp.241-251. 
Bhutta, M.K., Rana, A.I. and Asad, U. (2008) 'Owner characteristics and health of SMEs in Pakistan', Journal of Small Business and Enterprise Development, Vol. 15, No. 1, pp.130-149.

Bracker, J.S. and Pearson, J.N. (1986) 'Planning and financial performance of small mature firms', Strategic Management Journal, Vol. 7, No. 6, pp.503-522.

Bresciani, S. (2010) 'Innovation within firms. A survey in the Piedmont area', International Journal of Quality and Innovation, Vol. 1, No. 2, pp.138-152.

Bresciani, S. and Oliveira, N. (2007) 'Corporate environmental strategy: a must in the new millennium', International Journal of Business Environment, Vol. 1, No. 4, pp.488-501.

Broccardo, L. (2009) 'Family effects on management control: the case study of Italian SMEs working in plant engineering sector', Aidea Conference - Corporate Governance, Information and Control in an Evolutionary Context, Università Federico II di Napoli, Napoli, 3-4 April.

Brusa, L. (2012) Sistemi manageriali di programmazione e controllo, 2nd ed., Giuffrè, Milano.

Chenhall, R. (2003) 'Management control system design within its organizational context: findings from contingency-based research and directions for the future', Accounting Organizations and Society, Vol. 28, Nos. 2-3, pp.127-168.

Corbetta, G. (1995) Le imprese familiari. Caratteri originali, varietà e condizioni di sviluppo, Egea, Milano.

Corbetta, G., Montemerlo, D. and Gnan, L. (1997) Indagine sulle imprese familiari di piccole e medie dimensioni secondo il modello Mass Mutual, SDA Bocconi, Milano.

Dangayach, G.S. and Deshmukh, S.G. (2001) 'Manufacturing strategy: literature review and some issues', International Journal of Operations \& Production Management, Vol. 21 No. 7 , pp.884-932.

de Luca, A. (2010) 'Il Beyond Budgeting strumento gestionale emergente', Amministrazione e Finanza, Vol. 12, No. 52, pp.52-58.

Dematté, C. (2002) 'Gestione strategica: una prassi mal compresa e male applicata', Economia \& Management, Vol. 1, pp.3-12.

Engelen, P.J. and van Essen, M. (2013) 'Effects of firm-level corporate governance and country-level economic governance institutions on R\&D curtailment during crisis times', Governance, Regulation and Innovation, Vol. 58.

Ferraris, A. (2013) 'Innovative capacity of Italian manufacturing firms', Management, Vol. 3, No. 3, pp.174-183.

Fisher, J.G. (1998) 'Contingency theory, management control systems and firm outcomes: past results and future directions', Behavioral Research in Accounting, Vol. 10, No. 1, pp.47-64.

Garengo, P. (2009) 'A performance measurement system for SMEs taking part in quality award programmes', Total Quality Management, Vol. 20, No. 1, pp.91-105.

Garengo, P., Biazzo, S. and Bititci, U. (2005) 'Performance measurement systems in SMEs: a review for a research agenda', International Journal of Management Reviews, Vol. 7, No. 1, pp.25-47.

Giacomarra, M., Galati, A., Crescimanno, M. and Tinervia, S. (2016) 'The integration of quality and safety concerns in the wine industry: the role of third-party voluntary certifications', Journal of Cleaner Production, Part 1, Vol. 112, pp.267-274.

Hansen, S., Otley, D. and van der Stede, W.A. (2003) 'Practice developments in budgeting: an overview and research perspective', Journal of Management Accounting Research, Vol. 15, No. 1, pp.95-116.

Hansen, S.C. (2011) 'A theoretical analysis of the impact of adopting rolling budgets, activity-based budgeting and beyond budgeting', European Accounting Review, Vol. 20, No. 2, pp.289-319.

Hewa Wellalage, N. and Locke, S. (2012) Corporate governance and capital structure decision of Sri Lankan listed firms', Global Review of Business and Economic Research, 22 July, Vol. 8, No. 1, pp.157-169. 
Hilton, R.W. (2009) Managerial Accounting: Creating Value in a Dynamic Business Environment, 8th ed., Mc-Graw-Hill.

Hirst, M.K. (1987) 'The effects of setting budget goals and task uncertainty on performance: a theoretical analysis', The Accounting Review, Vol. 62, No. 4, pp.774-784.

Hope, J. (2007) 'Beyond budgeting to the adaptive organization', in Neely, A. (Ed.) Business Performance Measurement. Unifying Theory and Integrating Practice, Cambridge University Press, Boston.

Hope, J. and Fraser, R. (2003a) 'Who needs budgets?', Harvard Business Review, Vol. 81, No. 2, pp.108-115.

Hope, J. and Fraser, R. (2003b) 'Beyond budgeting: how managers can break free from the annual performance trap', Harvard Business School Press, Boston.

Horngren, C.T., Harrison, W.T., Bamber, L.S., Willis, B. and Jones, B. (2005) Accounting, Pearson Education.

Hudson, M. and Smith, D. (2000) 'Running before walking: the difficulties of developing strategic performance measurement systems in SMEs', EurOMA Conference Proceedings Operations Management, pp.292-298, Academia Press Scientific Publishers, Ghent.

Hvolby, H-H. and Thorstenson, A. (2000) 'Performance measurement in small and medium-sized enterprises', Proceeding of the International Conference on Stimulating Manufacturing Excellence in SMEs, 17-19 April, Coventry.

Jamil, C.Z.M. and Mohamed, R. (2013) 'The effect of management control system on performance measurement system at small medium hotel in Malaysia', International Journal of Trade, Economics and Finance, Vol. 4, No. 4, pp.202-208.

Jennings, P. and Beaver, G. (1997) 'The performance and competitive advantage of small firms: a management perspective', International Small Business Journal, Vol. 15, No. 2, pp.63-75.

Jonsson, P. and Matsson, S.A. (2003) 'The implication of fit between planning environments and manufacturing planning and control methods', International Journal of Operations and Production Management, Vol. 23, No. 8, pp.872-900.

Kraus, S., Harms, R. and Schwarz, E.J. (2006) 'Strategic planning in small enterprises: new empirical findings', Management Research News, Vol. 29, No. 6, pp.334-344.

Libby, T. and Lindsay, R.M. (2003) 'Booting the budget: how the BBRT envisions a world without budgets', CMA Management Magazine, April, pp.28-31.

Lyles, M.A. (1993) 'Formation of planning in small business', Journal of Small Business Management, April, Vol. 8, No. 1, pp.38-50.

Marchini, I. (1995) Il governo della piccola impresa, La gestione delle funzioni, Vol. 3, ASPI/INS-EDIT, Genova.

Marriott, N. and Marriott, P. (2000) 'Professional accountants and the development of a management accounting service for the small firm: barriers and possibilities', Management Accounting Research, Vol. 11, No. 4, pp.475-492.

Merchant, K. (1985) 'Budgeting and the propensity to create budgetary slack', Accounting, Organizations and Society, Vol. 10, No. 2, pp.201-210.

Omerzel, D.G. and Antoncic, B. (2008) 'Critical entrepreneur knowledge dimensions for the SME performance', Industrial Management and Data Systems, Vol. 108, No. 9, pp.1182-1199.

Østergren, K. and Stensaker, I. (2011) 'Management control without budgets: a field study of 'beyond budgeting' in practice', European Accounting Review, Vol. 20, No. 1, pp.149-181.

Reddaway, M., Goodman, S. and Graves, C. (2011) 'The role of accounting information in the management of winery SMEs: a review of the broader existing literature and its implications for Australia's wine industry', 6th AWBR International Conference, 9-10 June, Bordeaux Management School.

Ritchie, B. and Brindley, C. (2005) 'Cultural determinants of competitiveness within SMEs', Journal of Small Business and Enterprise Development, Vol. 12, No. 1, pp.104-119. 
Sian, S. and Roberts, C. (2006) Micro-Entity Financial Reporting: Some Empirical Evidence on the Perspectives of Preparers and Users, Information Paper, IFAC Small and Medium Practices Committee, New York, NY, December.

Simons, R. (1994) 'How new top manager use control systems as levers of strategic renewal', Strategic Management Journal, Vol. 15, No. 3, pp.169-189.

Soderquist, K., Chanaron, J.J. and Motwani, J. (1997) 'Managing innovation in French SMEs: an empirical study', BenchMarking for Quality Management and Technology, Vol. 4, No. 4, pp.259-272.

Thrassou, A., Vrontis, D. and Bresciani, S. (2014) 'Strategic Reflexivity in the hotel industry a value based analysis', World Review of Entrepreneurship, Management and Sustainable Development, Vol. 10, Nos. 2-3, pp.352-371.

Visconti, F. (2008) Scelte strategiche e posizionamento delle PMI, La guida del Sole 24 Ore alla Gestione delle PMI, Il Sole 24 Ore, Milano.

Wallander, J. (1999) 'Budgeting - an unnecessary evil', Scandinavian Journal of Management, Vol. 15, No. 4, pp.405-421.

Zimmerman, J.L. (2001) 'Conjectures regarding empirical managerial accounting research', Journal of Accounting and Economics, Vol. 32, No. 1, pp.411-427. 